\title{
CORPORATE LIABILITY FORMULATION POLICY ACCORDING TO ARTICLE 101 OF LAW NUMBER 31 OF 2004 JUNCTO LAW NUMBER 45 OF 2009 CONCERNING FISHERIES IN TERM OF CRIMINAL LEGAL REFORM IN INDONESIA
}

\author{
By: \\ Vivi Tri Kasih, Antory Royan A, Herlambang
}

\begin{abstract}
The corporation is the brain and source of funds for all illegal fishing activities and other crimes that occur along the chain of fishing business activities. According to Law Number 31 of 2004 in conjunction with Law Number 45 of 2009 concerning Fisheries, Article 101 states that: "In the case of a criminal acts as referred to in Article 84 paragraph (1), Article 85, Article 86, Article 87, Article 88, Article 89, Article 90, Article 91, Article 92, Article 93, Article 94, Article 95, and Article 96, the acts are committed by corporations; prosecution and criminal sanctions are imposed on their management and the fine is added by $1 / 3$ (one third) of the sentence imposed." It is necessary to renew the Fisheries Law in order to provide an overview in determining the Corporate Liability Formulation Policy according to Article 101 of Law Number 31 of 2004 in conjunction with Law Number 45 of 2009 concerning Fisheries in the context of Criminal Law Reform in Indonesia. The type of this research was normative by using primary, secondary and tertiary sources of legal materials. From the results of research and discussion, it was revealed that Corporate Liability according to Article 101 of Law Number 31 of 2004 in conjunction with Law Number 45 of 2009 concerning Fisheries in Indonesia currently does not explain things about the meaning of the word "management", which parties in the management structure of a corporation that can be held accountable, or to what extent the authority possessed by parties in the management structure of a corporation can be subject to criminal responsibility. Therefore, the Corporate Liability Formulation Policy according to Article 101 of Law Number 31 of 2004 in conjunction with Law Number 45 of 2009 concerning Fisheries in the context of Criminal Law Reform in the future should be changed, this is important considering the formulation stage is the most strategic stage in the efforts to prevent and to control crime by including / expanding criminal liability, not only for the management but also for the corporation and its management.
\end{abstract}

Keywords: Formulation Policy, Corporate Accountability, Fisheries Crime, Criminal Law Reform. 


\section{A. INTRODUCTION}

\section{Background of the Research}

The Unitary State of the Republic of Indonesia is a coastal state whose components of the national territory consist of land, oceans (waters) and air space, two thirds of the total territory of Indonesia is in the form of oceans, Indonesia can also be called an archipelagic state, the structure of the islands is widespread in the number of more than 17,508 small and large islands with a coastline of about $81,000 \mathrm{~km}$ in length. Approximately 6 million $\mathrm{km}^{2}$ of the territory of Indonesia is a sea which greatly affects the climate and weather throughout the region. ${ }^{1}$

The United Nations Food and Agriculture Organization (FAO) reports that in 2013, fully fished and overfishing waters have reached 90 percent of the total fishing area on earth. This figure increased significantly compared to year 1974 which was around 60 percent. Conversely, interest in marine fish consumption continues to increase in line with the increasing population of the earth. The aquaculture industry continues to be developed in various countries, but its existence has not been able to replace people's interest and the amount they need for marine fish. ${ }^{2}$

The high activity of Illegal, Unreported, and Unregulated Fishing (IUU Fishing) in The State Fishery Management Area of The Republic of Indonesia was confirmed by the results of a study conducted by the University of British Columbia, Canada (UBC Canada) in 2014. The study noted that in 2011, it was around 20-35 percent of tuna fish from Indonesia sent to the United States, with a volume of around 3,889 tons $-6,805$, tons are illegal and unreported. The study also revealed that Indonesian shrimp sold through Thailand and the People's Republic of China were not recorded in Indonesia's trade statistics. It was also reported that around 25 percent of the tuna caught by Vietnamese fishing vessels came from Indonesia's Exclusive Economic Zone waters. The fishing was carried out without a permit and without an agreement between Indonesia and Vietnam. ${ }^{3}$

The corporation becomes the brain and source of funds for all illegal fishing activities and other crimes that occur along the fishery value chain. The corporation is a legal subject and can be held accountable for the actions committed by the corporation. With mistakes that result in harm to society

\footnotetext{
${ }^{1}$ Mahendra Putra Kurnia, Hukum Kewilayahan Indonesia (Malang: UB Press, 2011), p.1.
}

${ }^{2}$ Susi Pudjiastuti, Laut Masa Depan Bangsa (Kedaulatan, Keberlanjutan, Kesejahteraan) (Jakarta: Ministry of Maritime Affairs and Fisheries of the Republic of Indonesia, 2017), p 30.

${ }^{3}$ Ibid, p.31. 
at large, a corporation can be held accountable. $^{4}$

Law Number 31 of 2004 in conjunction with Law Number 45 of 2009 concerning Fisheries Article 101 states that:

In the case of a criminal offense as referred to in Article 84 paragraph (1), Article 85, Article 86, Article 87, Article 88, Article 89, Article 90, Article 91, Article 92, Article 93, Article 94, Article 95, and Article 96 committed by the corporation, the charges and criminal sanctions are imposed on the management, and the fine is added by $1 / 3$ (one third) of the sentence imposed.

The Fisheries Law does not at all explain matters regarding the meaning of the word "management", which parties in the management structure of a corporation can be held accountable, or to what extent the authority possessed by parties in the management structure of a corporation can be held accountable.

With no recognition of corporate responsibility as perpetrators of criminal acts in fisheries crimes, in the implementation in the field only actors in the field such as the captain and crews are brought to trial. Meanwhile, the corporations that are behind them and actually get bigger profits from deviant fishing activities are totally

\footnotetext{
${ }^{4}$ Ibid, p.45.
}

untouched. Regarding the absence of regulations on when a corporation is deemed to have committed an offense, logically it is very difficult for the corporation to be charged as the perpetrator of the offense. ${ }^{5}$

It is necessary to renew the Fisheries Law in order to provide an overview in determining the Corporate Liability Formulation Policy according to Article 101 of Law Number 31 of 2004 in conjunction with Law Number 45 of 2009 concerning Fisheries in the context of Criminal Law Reform in Indonesia. The formulation stage is the most strategic stage of crime prevention because it is at this stage that guidelines are set for the implementation of the next stages, namely the application and execution stages. Crime prevention policies or efforts essentially aim at efforts to protect society (social defense) and to achieve social welfare.

\section{Identification of the Problem}

Based on the background above, the problem formulations in this study are as follows:

a. How was the Corporate Liability according to Article 101 of Law

\footnotetext{
${ }^{5}$ Pocut Eliza, Laporan Akhir Anlisis dan Evaluasi Hukum dalam Rangka Pemberantasan Kegiatan Perikanan Liar (IUU Fishing) (Jakarta: Ministry of Law and Human Rights of the Republic of Indonesia, 2016), p. 103.
} 
Number 31 of 2004 in conjunction with Law Number 45 of 2009 concerning Fisheries in Indonesia nowadays?

b. How was the Corporate Responsibility Formulation Policy according to Article 101 of Law Number 31 Year 2004 in conjunction with Law Number 45 of 2009 concerning Fisheries in the context of Criminal Law Reform in the future?

\section{RESEARCH METHOD}

\section{Type of Research}

The type of this research was in the category of normative legal research. Normative legal research is legal research conducted by examining library materials or secondary materials. ${ }^{6}$ The approaches used in legal research are as follows:

a. Statute Approach

In the statutory approach method, researcher need to understand the hierarchy and principles in statutory regulations. According to Article 1 point 2 of Law Number 10 of 2004, statutory regulations are written regulations established by state institutions or authorized officials and are generally binding. ${ }^{7}$

b. Conceptual Approach

The conceptual approach is carried out when the researcher does not move from the existing legal rules. This approach has a close relationship with the views and doctrines that are developed in the science of law. The concept of law can also be found in law. It is just that in identifying these principles the researcher should first understand the concept through existing views and doctrines. ${ }^{8}$

c. Comparative Approach

The comparative approach is carried out by conducting a comparative legal study. According to Gutteridge, comparative law is a method of legal study and research. Gutteridge distinguishes between descriptive legal comparisons whose main purpose is to obtain information and comparisons of applied laws that have a specific goal. $^{9}$

\section{Sources of Legal Materials}

a. Primary Legal Material
${ }^{6}$ Soerjono Soekanto dan Sri Mamudji, Penelitian Hukum Normatif Suatu Tinjauan Singkat (Jakarta: Raja Grafindo Persada, 2010), p. 13.
${ }^{7}$ Peter Mahmud Marzuki, Penelitian Hukum (Jakarta: Kencana, 2010), p. 96.

${ }^{8}$ Ibid, p.137-138.

${ }^{9}$ Ibid, p.132 
Primary legal materials are binding legal materials ${ }^{10}$, especially those regulating the Corporate Liability Formulation Policy according to Article 101 of Law Number 31 of 2004 in conjunction with Law Number 45 of 2009 concerning Fisheries in the context of Criminal Law Reform in Indonesia.

b. Secondary Legal Material

Secondary legal materials are legal materials that provide an explanation of primary legal materials $^{11}$, such as the Draft of Criminal Code, research results or legal expert opinion.

c. Tertiary Legal Material

Tertiary legal materials are materials that provide guidance and explanation for primary and secondary legal materials, such as legal dictionaries and encyclopedias. $^{12}$

\section{RESULT AND DISCUSSION}

1. Corporate Responsibility According to Article 101 of Law Number 31 of 2004 Juncto Law Number 45 of 2009 Concerning Current Fisheries In Indonesia

\footnotetext{
${ }^{10}$ M. Amuriddin and Zainal Asikin, Pengantar Metode Penelitian Hukum (Jakarta: RajaGrafindo Persada, 2004), p. 118.

${ }^{11}$ Ibid, p.119

${ }^{12}$ Ibid.
}

\section{a. Criminal Code (KUHP)}

The current Criminal Code $(K U H P)$ does not yet regulate corporate responsibility, meaning that they do not recognize corporations as the subject of criminal acts.

b. Law Number 31 of 2004 concerning Fisheries, as amended by Law Number 45 of 2009 concerning Amendments to Law Number 31 of 2004 concerning Fisheries

Indonesia as an archipelagic country, most of whose territory consists of the sea, has enormous and varied fishery potential. The fishery potential that is owned is an economic potential that can be utilized for the future of the nation, as the backbone of national development. Optimal utilization is directed at the utilization of fish resources by taking into account the existing carrying capacity and its preservation to improve people's welfare, improve the standard of living of small fishermen and small farmers, increase revenue from the state foreign exchange, provide expansion and job opportunities, increase productivity, added value and power. competitiveness of fishery products and ensuring the sustainability of fish resources, fish cultivation land, and spatial planning. This means that the utilization of fishery resources must be balanced with its carrying 
capacity so that it is expected to provide continuous benefits. One of them is done by controlling fisheries business through fisheries management arrangements $^{13}$.

The United Nations Convention on the Law of the Sea, 1982, which was ratified by Law Number 17 of 1985 concerning Ratification of the United Nations Convention on the Law of the Sea 1982, places Indonesia as having sovereign rights to carry out utilization, conservation, and management of fish resources in Indonesian Exclusive Economic Zone (EEZ) and the high seas which are carried out based on applicable international requirements or standards ${ }^{14}$.

Therefore, a legal basis for fish resource management is needed that can accommodate all aspects of fish resource management and anticipate the development of legal and technological needs. The presence of the Fisheries Law is expected to be able to anticipate as well as a solution to enormous changes in the fisheries sector, both

\footnotetext{
${ }^{13}$ Elucidation on Law of the Republic of Indonesia Number 45 of 2009 concerning Amendments to Law Number 31 of 2004 concerning Fisheries.
}

${ }^{14}$ Ibid. related to the availability of fish resources, environmental sustainability of fish resources, as well as the development of more effective, efficient and modern fisheries management methods. ${ }^{15}$. The Fisheries Law has been amended three times. Starting from the first Fisheries Law is Law Number 9 of 1985 concerning Fisheries. The second Fisheries Law, amended by Law Number 31 of 2004 concerning Fisheries. The third Fisheries Law is Law Number 45 of 2009 concerning Amendments to Law Number 31 of 2004 concerning Fisheries.

On the other hand, several issues in fisheries development need the attention of all parties, including the government, society, and other parties related to fisheries development. These issues include the symptoms of overfishing, fishing theft, and other illegal fishing actions which not only cause losses to the state, but also threaten the interests of fishermen and cultivators, the industrial climate, and the national fisheries business. ${ }^{16}$. These problems must be 
resolved seriously so that law enforcement in the fisheries sector becomes very important and strategic to support controlled and sustainable fisheries development. The existence of legal certainty is a condition that is necessary for handling criminal acts in the field of fisheries.

However, in reality, the current Fisheries Law is still unable to anticipate technological developments as well as the development of legal needs in the context of managing and exploiting potential fish resources and has not been able to answer these problems. Therefore it is necessary to make changes to several substances, both regarding aspects of management, bureaucracy, and legal aspects ${ }^{17}$.

According to Law Number 31 of 2004 in conjunction with Law Number 45 of 2009 concerning Fisheries Article 101 states that:

In the case of a criminal offense, as referred to in Article 84 paragraph (1), Article 85, Article 86, Article 87, Article 88, Article 89, Article 90, Article 91, Article 92, Article 93, Article 94, Article 95, and Article 96 committed by the corporation, the charges and criminal sanctions imposed on the management and the fine is added by $1 / 3$ (one third) of the sentence imposed.

The Fisheries Law does not at all explain matters regarding the meaning of the word "management", which parties in the management structure of a corporation can be held accountable, or to what extent the authority possessed by parties in the management structure of a corporation can be held accountable, be liable to criminal responsibility. The management structure of a corporation is not only one party in it. Likewise, the work units in the company do not consist of just one unit. Certainly, these work units are controlled by several people with their respective authority. Likewise, criminal responsibility is borne by the managers who work in the field or given to their superiors. If these things are not determined, it will be very difficult to determine which party in the management structure of a corporation is responsible.

\section{Corporate}

Responsibility

Formulation Policy According to Article 101 of Law Number 31 of 2004 Juncto Law Number 45 Of 2009 Concerning Fisheries In The Concerning Criminal Legal Reform in the Coming Time 
a. The Draft of Criminal Code (RUU

\section{KUHP) September 2019}

The Draft of Criminal Code

(RUU KUHP) September 2019 has

regulated corporate responsibility in

Paragraph 3 of Article 45, Article

46, Article 47, Article 48, Article

49, Article 50.

\section{Art 45}

1) The corporation is the subject of a criminal act.

2) Corporations, as referred to in paragraph (1), include legal entities in the form of limited liability companies, foundations, cooperatives, state-owned enterprises, region-owned enterprises, or the equivalent, as well as associations, both legal and non-legal entities or business entities in the form of a firm, limited partnership, or its equivalent in accordance with the provisions of laws and regulations.

\section{Art 46}

Criminal Actions by Corporations are criminal acts committed by managers who have a functional position in the organizational structure of the Corporation or persons based on work relations or based on other relationships acting for and on behalf of the Corporation or acting in the interests of the Corporation, within the scope of business or activities of the Corporation. either individually or collectively.

\section{Article 47}

In addition to the provisions as referred to in Article 46, Criminal Actions by Corporations can be carried out by the issuer of orders, control holders, or beneficial owners of the Corporation who are outside the organizational structure but can control the Corporation.

\section{Article 48}

Criminal acts by corporations as referred to in Article 46 and Article 47 can be accounted for, if:

a) included in the scope of business or activities as stipulated in the articles of association or other provisions applicable to the Corporation;

b) benefit the Corporation unlawfully; and

c) accepted as a Corporation policy.

\section{Art 49}

Liability for Criminal Actions by the Corporation as referred to in Article 48 shall be imposed on the Corporation, the manager who has a functional position, the issuer of the order, the holder of control, and/or the beneficial owner of the Corporation.

\section{Art 50}

A justification that can be submitted by a manager who has a functional position, issuer of order, control holder, or beneficial owner of the Corporation can also be submitted by the Corporation as long as the reason is directly related to the Criminal Act that is accused of the Corporation. 
With the existence of regulations in the current Criminal Code Draft, it will certainly make the uniformity of regulations regarding corporations as subjects of criminal law, and it is hoped that it will add articles related to corporate responsibility in the fisheries sector.

\section{b. Corporate Liability in the Future}

According to Law Number 31 of 2004 in conjunction with Law Number 45 of 2009 concerning Fisheries Article 101 states that:

In the case of criminal action, as referred to in Article 84 paragraph (1), Article 85, Article 86, Article 87, Article 88, Article 89, Article 90, Article 91, Article 92, Article 93, Article 94, Article 95, and Article 96 committed by the corporation, the charges and criminal sanctions imposed on the management and the fine is added by $1 / 3$ (one third) of the sentence imposed.

The Fisheries Law does not at all explain matters regarding the meaning of the word "management", which parties in the management structure of a corporation can be held accountable, or to what extent the authority possessed by parties in the management structure of a corporation can be held accountable. be liable to criminal responsibility. The management structure of a corporation is not only one party in it. Likewise, the work units in the company do not consist of just one unit. Certainly, these work units are controlled by several people with their respective authority. Likewise, criminal responsibility is borne by the managers who work in the field or given to their superiors. If these things are not determined, it will be very difficult to determine which party in the management structure of a corporation is responsible.

In certain cases where the profits obtained by the company are so large and/or the losses by the community are so large, the imposition of imprisonment/fines only on the corporate management will be disproportionate. In addition, the imposition of criminal sanctions on corporate management is also not sufficient to guarantee that the corporation will not commit similar actions in the future. Not a few corporations are also hiding behind dummy companies that they deliberately set up to protect their parent corporations.

According to Article 101 of Law Number 31 of 2004 in conjunction with Law Number 45 of 2009 concerning Fisheries in the context of Criminal Law Reform in 
the future, this provision should be changed, this is important considering the formulation stage is the most strategic stage in the Corporate Liability Formulation Policy in the efforts to prevent and control crimes by including/expanding criminal responsibility not only for management but also for corporations and their managers must be explained.

\section{CLOSING}

\section{a. Conclusion}

a. Corporate Responsibility according to Article 101 Law Number 31 of 2004 in conjunction with Law Number 45 of 2009 concerning Fisheries in Indonesia currently does not explain anything about the meaning of the word "management", which parties are in the management structure of corporations that can be held accountable, or to what extent the authority possessed by parties in the management structure of a corporation can be subject to criminal responsibility.

b. According to Article 101 of Law Number 31 of 2004 in conjunction with Law Number 45 of 2009 concerning Fisheries in the context of Criminal Law Reform in the future, this provision should be changed, this is important considering the formulation stage is the most strategic stage in the Corporate Liability Formulation Policy in the effort to prevent and control crimes by including/expanding criminal responsibility not only for management but also for corporations and their managers must be explained.

\section{b. Suggestion}

a. The Fisheries Law must be enforced effectively and efficiently so that law enforcement can have a deterrent effect and return state losses.

b. Criminal sanctions are inconsistent, so it is necessary to carry out an assessment of the system of imposing sanctions that is more beneficial to the state.

\section{REFERENCES}

M. Amuriddin and Zainal Asikin, Pengantar Metode Penelitian Hukum (Jakarta: RajaGrafindo Persada, 2004).

Mahendra Putra Kurnia, Hukum Kewilayahan Indonesia (Malang: UB Press, 2011).

Peter Mahmud Marzuki, Penelitian Hukum (Jakarta: Kencana, 2010).

Pocut Eliza, Laporan Akhir Anlisis dan Evaluasi Hukum dalam Rangka Pemberantasan Kegiatan Perikanan Liar (IUU Fishing) (Jakarta: Ministry 
of Law and Human Rights of the Republic of Indonesia, 2016).

Soerjono Soekanto dan Sri Mamudji, Penelitian Hukum Normatif Suatu Tinjauan Singkat (Jakarta: Raja Grafindo Persada, 2010).

Susi Pudjiastuti, Laut Masa Depan Bangsa (Kedaulatan, Keberlanjutan, Kesejahteraan) (Jakarta: Ministry of Maritime Affairs and Fisheries of the Republic of Indonesia, 2017), p 30.

Elucidation on Law of the Republic of Indonesia Number 45 of 2009 concerning Amendments to Law Number 31 of 2004 concerning Fisheries. 